\title{
'Reading' the Leichhardt, Landsborough and Gregory Explorer Trees of Northern Australia
}

\author{
RICHARD J. MARTIN \\ UNIVERSITY OF QUEENSLAND
}

-INTRODUCTION

Like many first-time visitors to Borroloola, I went to the town's small museum shortly after arriving to begin anthropological fieldwork in mid-2007. Located in the Northern Territory's oldest surviving police station, which dates from 1887, the museum was created in the mid 1980s as a result of the loving efforts of an amateur historian named Judy Cotton. ${ }^{1}$ Inside the museum, amidst the flotsam and jetsam of the town's colonial history-weathered saddles, rusted stirrups, dingo traps, broken spectacles, glass bottles, moth-eaten uniforms, reproduced photographs, scraps of text-is the trunk of an ironwood tree (Erythrophleum chlorostachys) that was reportedly blazed by Ludwig Leichhardt during his first expedition from Moreton Bay to Port Essington in 1844 to $1845 .^{2}$ Originally situated on the edge of the Calvert River, the trunk was moved to the Borroloola museum in $1985 .{ }^{3}$ Rooted in iron now rather than soil, its location in the museum draws attention to the politics of heritage and history in this small town. With the Northern Territory Police Force's involvement in the violence of colonial settlement, the placement of the tree in 
Borroloola's Old Police Station Museum is in some ways an aggressively political act, illustrative of conservative attempts to portray the explorers as heroic founders of modern Australia. In many ways, this tree is a paradigmatic example of what Paul Carter called 'spatiality as a form of non-linear writing; a form of history', the study of which reveals the process of 'transforming space into place' in 'the intentional world of the texts'. ${ }^{4}$ However, while seemingly amenable to such textual analysis manifesting a straightforward critique of the hegemony of nationalist imperial history, alternative responses to the 'Leichhardt tree' emerged as I completed fieldwork in Borroloola. These pointed to a continuing struggle over the meaning of exploration, and colonisation, in northern Australia.

Alongside the Leichhardt tree in Borroloola, in this article I examine theoretical and methodological issues provoked by local responses to two other landmark 'explorer' trees. The first of these is a coolibah (Eucalyptus coolabah) marked by William Landsborough during his search for the missing explorers Burke and Wills in 1862. This Landsborough tree was destroyed by an act of arson in 2002 in an event that continues to provoke heated passions among the residents of nearby Burketown, northwest Queensland. Like the placement of the Leichhardt tree in the Borroloola Police Station Museum, the act of arson invites a politicised interpretation to serve contemporary identity politics. But, as I have suggested with regard to the Leichhardt tree, a more complex interpretation emerges through a combination of textual analysis and ethnographic fieldwork. The other tree is a boab (Adansonia gregorii) on the edge of the Victoria River in the Northern Territory, its botanical name bestowed by the botanist Ferdinand von Mueller in honour of the leader of the North Australian Expedition, Augustus Gregory. Marked by Gregory during his expedition of 1855-56, this Gregory tree is also a registered Aboriginal sacred site because of its connection to a ceremony for Ngarinman people living at nearby Timber Creek. I argue that, as with the Leichhardt and Landsborough trees, predominantly textual 'readings' of the Gregory tree are immeasurably enriched by ethnography. At the same time, all three trees remain meaningful in ways even the richest ethnography cannot exhaust, generating a series of conflicting and overlapping explanations that cannot be reduced to a single or even dual interpretation. 
Seeking to avoid reductive characterisations of either cultural studies or anthropology, I argue that a combination of approaches from both disciplines provides a richer interpretation than either may accomplish on its own. Scholars in cultural studies and anthropology have historically engaged in debate about the relative merits of each discipline's methodologies, particularly in research addressing Aboriginal Australia, but I argue that such debate distracts from the possibilities of interdisciplinary analysis. ${ }^{5}$ With regard to the 'explorer' trees of northern Australia-marked by readable letters in the English alphabet, yet meaningful in other ways-I argue for an approach to interpretation that attends to textuality without attributing meaning solely to the 'writer' and 'reader' of the text, emphasising creative representations which make meanings proliferate. To do so, I critique the textual tradition of 'reading' settler-colonial artefacts, and draw selectively from work in material culture. As Marilyn Strathern argues, the analytical separation of social and cultural contexts from material things including texts renders the study of such things somewhat superfluous as they can only function to illustrate the systems within which their significance is produced.6 Similarly, the authors of a recent collection in material cultural analysis argue:

Rather than accepting that meanings are fundamentally separate from their material manifestations (signifier v. signified, word v. referent, etc), the aim is to explore the consequences of an apparently counter-intuitive possibility: that things might be treated as sui generis meanings. [emphasis in the original $]^{7}$

This approach offers an alternative practice to the textual tradition of 'reading' things. While this alternative practice presents challenges, it offers a way to bring methods from cultural studies and anthropology into conversation with each other around the richly symbolic-but also non-symbolic, non-representational-explorer trees of northern Australia. ${ }^{8}$

\section{—BICENTENNIAL POLITICS AND THE OLD DEAD TREE OF AUSTRALIAN NATIONALISM}

Across the north of Australia, there is a constant summoning of the colonial past, particularly within touristic space; lots of cafés have little historical displays and there are explorer-themed inns in many towns. There is also a long-established tradition of exploration literature, going back to the romantic epistles of Ernestine 
Hill in the 1930s, 1940s and 1950s and the frontier histories of Glenville Pike in the 1960s and 1970s, to the constant reissue of explorer journals and narrative histories into the present, like Sarah Murgatroyd's bestselling The Dig Tree: The Story of Burke and Wills. ${ }^{9}$ Many scholars have addressed the mythology of the explorers in northern Australia, including the anthropologists Erich Kolig, Athol Chase, Kenneth Maddock and Deborah Bird Rose around the time of Australia's Bicentennial and, more recently, the cultural studies scholars Chris Healy and Stephen Muecke.10 Focusing particularly on Aboriginal understandings of Captain Cook, Kolig, Chase, Maddock and Rose describe accounts from New South Wales, Queensland, the Northern Territory and Western Australia in which Cook is depicted shooting at Aboriginal people from a horse, bringing violence to the land. In Healy's analysis, such examples illustrate a broad contrast between Aboriginal responses to the story of Captain Cook and those of non-Aboriginal people. For Healy, Cook is 'an enduring icon, a huge network of narratives, images and ceremonies', albeit one best understood, in his view, within a racialised dichotomy. ${ }^{11}$ As Muecke puts it, following Healy:

In Australian history, Captain Cook has become a pivot for these false perceptions of 'ancient' [relating to Aboriginal people] and 'modern' [relating to non-Aboriginal people]. This is perhaps why, as a sense of historical injustice drove people in the 1960s to do the work of assembling Aboriginal histories, the revisionist backlash that followed it in the 1990s centred on Cook as a necessary and heroic redeemer of white centrality, if not superiority. ${ }^{12}$

To support this argument, Muecke travels to a monument to Cook at Kurnell in southern Sydney and to the Captain Cook Motel in Cairns, contrasting his reading of these sites with the experience of touching a miniature souvenir model of the ship Endeavour. For Muecke, the truism that history is 'constructed' supports his own interpretative reading of these things (the Kurnell monument, the Captain Cook Motel, the souvenir of the Endeavour) as part of what he calls 'a negotiable world of heterogeneities' that provides a necessary counterpoint to the arguments of conservative 'historians' like former Australian prime minister John Howard. ${ }^{13}$ Muecke particularly critiques the then-Liberal member of parliament for Cronulla, Malcolm Kerr, for objecting to the removal of non-indigenous vegetation around the 
Cook monument at Kurnell, interpreting this as an example of the further dispossession of Aboriginal people. However, Muecke's assertions about politicised perceptions of explorers is arguably over-stated, neglecting to engage with the diverse and indeed heterogeneous ways in which figures like Cook are remembered outside the partisan context that he describes. Indeed, despite making reference to John Howard's tenure as Australia's prime minister throughout the late 1990s and early 2000s, Muecke's analysis seems to date from the earlier period, the 1960s to the 1990s, when the politics of Aboriginal and non-Aboriginal identities were perhaps more polarised than they are today. Closer attention to current responses to the myth of the explorers reveals different approaches to the colonial past.

In the first volume of his classic history of Australia, Manning Clark records that the English 'began their ceremonies in Australia' when Captain Cook directed 'an inscription to be cut on one of the trees near the watering place setting forth the ship's name, and the date of their arrival'.14 In the late 1950s, Patrick White explored this in Voss. At the end of that novel at the unveiling of a statue of the disappeared Voss, the surviving characters reflect on what they see as the continuing presence of the explorer in the landscape.

'Voss left his mark on the country,' he said.

'How?' asked Miss Trevelyan, cautiously.

'Well, the trees, of course. He was cutting his initials in the trees. He was a queer beggar, Voss. The blacks talk about him to this day. He is still therethat is the honest opinion of many of them-he is there in the country, and always will be.'15

In Borroloola's Police Station Museum, one such explorer tree is commemorated today in a display created for the bicentennial of Australian settlement by Europeans. For tourists following in the footsteps of the explorers-particularly Leichhardt, whose expedition from Moreton Bay near modern-day Brisbane to Port Essington near Darwin took him through the area of modern-day Borroloola-sites like this Leichhardt tree are necessary and indispensable, making the intangible past somehow present, and past environments putatively the same. 


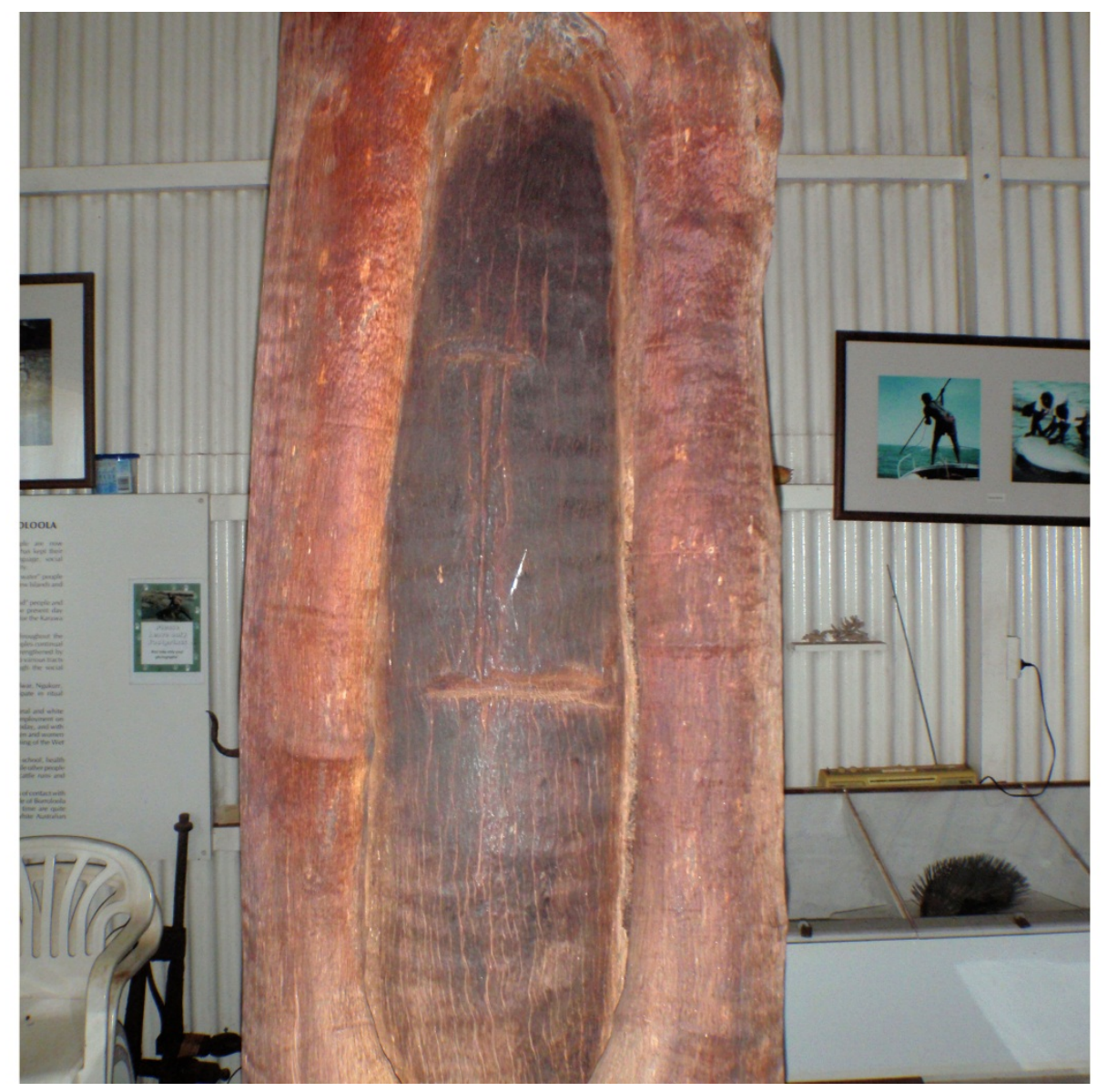

Image 1: Leichhardt tree in the Borroloola Museum

Photograph by li-Anthawirriyarra Sea Ranger Unit, April 2013

In many ways the display in Borroloola's Police Station Museum evokes what Manning Clark called English 'ceremonies', revisiting the moment of European settlement when Australia's Aboriginal population was summarily dispossessed of their land. Aside from some photographs taken by the ethnographers Spencer and Gillen in 1901, and several more recent images depicting Aboriginal people engaged in neotraditionalist activities like dugong hunting with harpoons, most of the museum's displays ignore the lives of the Aboriginal groups who presently live in the town and present a view of Australia's past that appears to be ideologically consistent with that described by W.E.H. Stanner in his 1968 Boyer lectures as a 'cult of forgetfulness practiced on a national scale'.16 As Stanner describes it, this form of active 'dis-remembering' extends beyond an ignorance of frontier violence (in which the police force commemorated in the Police Station Museum were involved) into a 
general lack of attention to Aboriginal people at all, beginning in the early twentieth century and lasting into the 1960s and beyond. In some ways the Borroloola display substantiates this form of conservative history, highlighting what Mark McKenna calls the peculiar 'sense of fragility' felt by many locals in his study region of southeast New South Wales:

The belief that settler history needed to be sheltered and housed, to be made visible and given a physical presence, suggested that a people without a history were a people without a soul, a community without a shared memory. ${ }^{17}$

McKenna ties this sense of fragility to what he calls "a race to become "historic" in Australia, as if every park stump is a historical treasure'. Drawing on colonial archives relating to Bega Shire in New South Wales, he argues that settlers sought to distance themselves quickly from the early colonial period to replace 'the "darkness" of thousands of years of Aboriginal occupation ... with a new creation story'.18 Here in Borroloola's unprepossessing Police Station Museum, McKenna's interpretation building on Stanner's insight into the psychology of the Great Australian Silence seems borne out. Symbolising non-Aboriginal Australians' cultural roots in the soil (albeit roots that have been chopped off to fit the tree into the display), this Leichhardt tree is posited as a tangible material link to the first Europeans in the southern Gulf in the textual material that surrounds and literally supports the tree. It is noteworthy that the display was created in 1985, three years before Australia's bicentenary celebrations, when questions of Australian identity were at the forefront of the national consciousness and funding was available for projects like the Borroloola museum. More recent displays like those in Canberra's Australian Museum have pursued an alternative interpretation of Australia's past, but those like Borroloola's Police Station Museum continue to exist, evoking the conservative nationalist histories of previous times.

However, to interpret the Leichhardt tree in Borroloola only within this context is somewhat limited. The display is highly evocative of conservative histories and readily amenable to the type of analysis that critics from the 1980s and early 1990s pursued under labels like post-colonialism, but readings like this have become almost clichéd, shrill rejoinders in what are known as 'the history wars'.19 This conflict or 'war' dates from around the time of Australia's bicentennial in 1988, 
when Manning Clark famously declared that the coming of the British was the occasion for three great evils: the violence against the original inhabitants of the country, the Aboriginals; the violence against the first European labour force in Australia, the convicts; and the violence done to the land itself'.20 For Clark, conservative politics as exemplified by former prime minister Sir Robert Menzies represented The Old Dead Tree of Australian nationalism; the wartime Labor prime minister John Curtin, by contrast, was a younger sapling, whose premature death denied him 'the glory of teaching Australians how to cultivate "The Young Green Tree"'. ${ }^{21}$

But while Clark's symbolism is appropriate here, the comparison is not, reiterating problematic readings of settler-colonial artefacts like the explorer trees. When I first visited Borroloola in 2007, many of the local residents and interstate tourists whom I interviewed had not been inside the museum. Moreover, several of those who had visited the museum had failed to notice the tree, or had not accorded it much significance, dwelling instead on other displays. One pair of tourists who had rented a plane to retrace the journey of Burke and Wills-and ended up in Borroloola, far from Burke and Wills' track, when their plane broke down-spoke instead of their admiration for a display about an inter-racial relationship between a non-Aboriginal man and two Aboriginal women at Borroloola in the 1940s, finding in these photographs support for their understanding of the policy of reconciliation. Asked about their motivations for following Burke and Wills, they spoke of the explorers' 'fatal flaw' in an interview I transcribed at the time: 'see they failed to engage with the Aborigines, that would have kept them alive, they were just pompous old Englishmen really, nothing like modern Australians, but you can sense the start of Australianness in their story'. Clearly, for these self-styled modern-day explorers, The Young Green Tree of Australian nationalism need not involve the repudiation of Australia's past, nor any simplistically politicised interpretation of this past along the lines laid out by Clark.

Indeed, contrary to McKenna's analysis and the argument of theorists like Svetlana Boym-who makes a distinction between intentional and unintentional monuments or readings thereof, unintentional monuments being those that introduce uncertainty, unexpected juxtapositions and colliding time schemes into their interpretation-it is worth noting that any presentation of the past in 
monumental form is necessarily polysemic. ${ }^{22}$ Just as Scott Sandage shows how African-American civil rights groups appropriated the Lincoln Memorial as a site for articulating their claims in the 1960s-'in the process layering and changing the public meanings of the hero [Lincoln] and his shrine'-it is possible to document how monuments associated with the explorers have been re-interpreted across northern Australia to suggest all sorts of things other than and even contrary to their apparently intentional purpose. ${ }^{23}$ As such, it is flawed to interpret displays like those in the Borroloola museum using overly deterministic analyses in line with Althusserian orthodoxy about the interpellation of subjects in support of dominant ideological regimes. Instead, the interpretation of things like the Leichhardt tree requires a broadly interdisciplinary approach to the study of culture; one that goes beyond the notion of culture as text or an ensemble of texts that can be read by the analyst 'over the shoulders of those to whom they properly belong' (as Geertz puts it) to consider text as something arising from and referring to cultural practices. ${ }^{24}$ Utilising anthropological methodologies, such cultural practices may be studied ethnographically. ${ }^{25}$ However, through the interpretation of objects like these explorer trees I suggest that such things continue to produce new meanings through the interaction of all the functions of the text, including the 'reader' and the 'writer', as well as the materiality of the medium itself. While I resile from attempts to ascribe agency-if not intention-to material objects, the study of the relations between humans and things in science and technology studies, and actor network theory, is relevant to the analysis of such meaning-making. ${ }^{26}$ The productivity of this kind of theory is evident when interpreting the Landsborough tree at Burketown at Burketown and the Gregory tree (or trees) near Timber Creek, for which understandings of corporality, materiality and sociality are required.

—STRUGgLES OVER HERITAGE IN LAND RIGHTS AND NATIVE TITLE TIME

A shift to Burketown in northwest Queensland reveals a different interpretation of northern Australia's explorer trees. The 150th anniversary of Burke and Wills' journey from Melbourne to the coast of Carpentaria occurred in 2011. At Burketown-named after the explorer Robert O'Hara Burke as part of the Colony of Victoria's unsuccessful attempt to claim this area from the Colony of Queenslandthe town's annual social ball was themed 'Burke and Wills' and numerous tourists 
intent on retracing the journey of the explorers passed through the town (even though Burke and Wills never travelled near the location of modern-day Burketown). The enterprising Diamantina Touring Company even organised a fully catered twenty-night camping trip costing $\$ 5500$ Australian dollars, involving travel from Melbourne to Burketown and Karumba. ${ }^{27}$ Burketown lacks any sites specifically associated with Burke and Wills, so a tree marked by the explorer William Landsborough (who led a party in search of Burke and Wills when those more famous explorers failed to return home) was monumentalised. In his Exploration of Australia from Carpentaria to Melbourne, Landsborough wrote:

The importance of marking trees cannot be overrated. The marks should only be made on strong, healthy trees, and at conspicuous points; and the directions should be unmistakeably clear and accurate. 28

True to his stated instructions, Landsborough left a trail of blazed trees from the Albert River to the Warrego River during his 1862 expedition, thereby describing a practical route for overlanding stock to western and northwest Queensland later followed by pastoralists in the frenzied land rush that occurred after the publication of Landsborough's account. ${ }^{29}$ When I arrived at the site of the tree outside Burketown in 2007, however, I found nothing but a small charred stump. In December 2002, the Landsborough tree was destroyed in an act of arson.

I later had the chance to interview the volunteer curator of a small local history museum in the old post-office building at Burketown. In the late 1990s, Frank Thomas convinced the local council to grant him the lease over the old post-office. He then filled this space with all sorts of brochures, maps, old photographs, newspaper clippings and displays, almost all of which relate to non-Aboriginal history. But in some respects the museum is a memorial to the tree, with numerous newspaper clippings about the arson, as well as reproductions of historical photographs. The council lets Frank maintain a workshop out the back in return for his volunteer work curating and staffing the museum. For a man who spends most of his day talking to tourists about the condition of the road, I expected him to be garrulous about the tree but words failed him when I asked about it. 'It's just a waste', he said. 'It's gone now for good, a beautiful old tree like that'. A keen amateur woodworker, he crafted a number of souvenirs from the wood of the old tree, including a wine stopper he gave to me. 


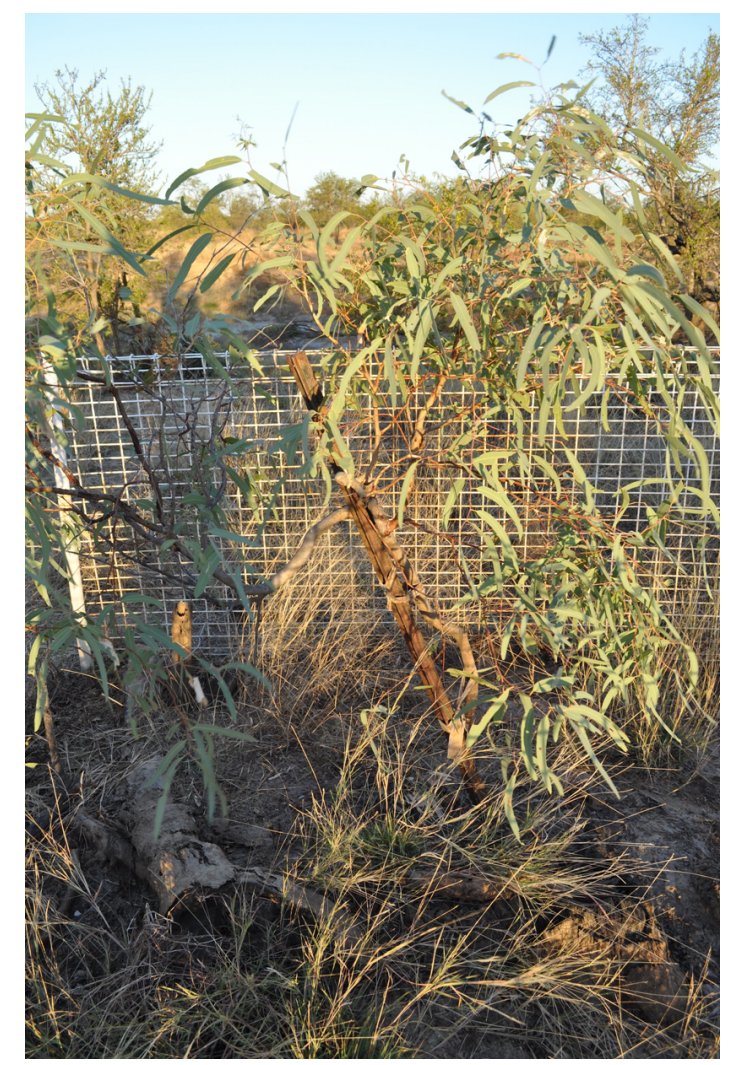

Image 2: Landsborough tree site, showing replanted sapling alongside part of the destroyed tree Source: photograph by author, June 2009

Many other non-Aboriginal people in the area were more expressive than Frank about the loss of the tree, interpreting the event in terms of the racial politics of the town. Queensland's then-Minister for Police and Corrective Services Tony McGrady (whose electorate of Mount Isa encompassed Burketown) described the act as 'unAustralian'. 'It is part of our history', he told the Australian Associated Press, 'and louts, the lowest of the low, have seen fit to destroy it, which is very disappointing for everybody.' 30 While McGrady allows that the arsonists may not have been Aboriginal, other commentators were less circumspect. Many locals I interviewed blamed the arson on a man of mixed-Aboriginal and non-Aboriginal descent who reportedly burnt down the tree in a berserker rage provoked by his eviction from the pub. As I came to know this community better over several years of fieldwork, I was offered various other explanations, including from one informant who told me 'everything is connected' in such a pronounced stage whisper that I leant forward in my chair. It all began, he claimed, with a misjudged allocation of government 
housing to an Aboriginal family from Doomadgee. As soon as the bureaucrat who made the decision left town, the house was alight. This provoked a series of arson attacks that exacerbated tensions associated with the distribution of royalties from the Century Lead and Zinc mine and drew in the town's non-Aboriginal community, leading to the arson of the town's Shire Council building in 1999. According to this informant's interpretation, this arson functions in much the same way as Geertz's thick description of the cockfight in Bali, highlighting everything there is to know about Burketown and the broader southern Gulf if the anthropologist is simply diligent enough to pursue all the different explanations. ${ }^{31}$ And indeed much later, at the end of a fieldtrip with a group of Aboriginal people, one of those present made a boast to me that he knew who was involved, stating: 'we [local Aboriginal people] did it ... to show those fucking White cunts what it's like, if they won't respect us, we won't respect them'.

But while this boast might be thought to resolve the question of what the arson meant-and furnish an account of a community riven by conflict between Aboriginal and non-Aboriginal people-other readings remain possible. My above informant's boast may obviously be empty. It might also be self-serving, seeking to connect the arson to a supposed political campaign rather than a drunkard's berserker rage or any of a number of other motivations arising from the politics of the town. Furthermore, while we might seek to privilege the above informant's presentation of the act as politically motivated arson alongside an aggregation of different readings of the event, it seems more than a little rash to extrapolate beyond that to provide a structurally deterministic account, however heteroglossic such an account might be.

The event of the arson and indeed the symbolism of the tree remain meaningful in ways that even the richest ethnography can never exhaust, generating polysemic as well as polythetic readings without end; meanings that share a number of characteristics but cannot be used as a system or mechanism of classification. For example, on a repeat visit to the site of the tree in mid-2009 I noticed a new piece of graffiti on the information board: "The tree was burnt down (desecreated) by some of the "locals" in similar pattern as the Roper Bar Police Station, Jardine's "Somerset" in Albany Pass and several other historical sites'. It is tempting to interpret this inscription as the work of someone outraged at the loss of the tree, as it seemingly connects the arson with a concerted political campaign to damage or indeed 


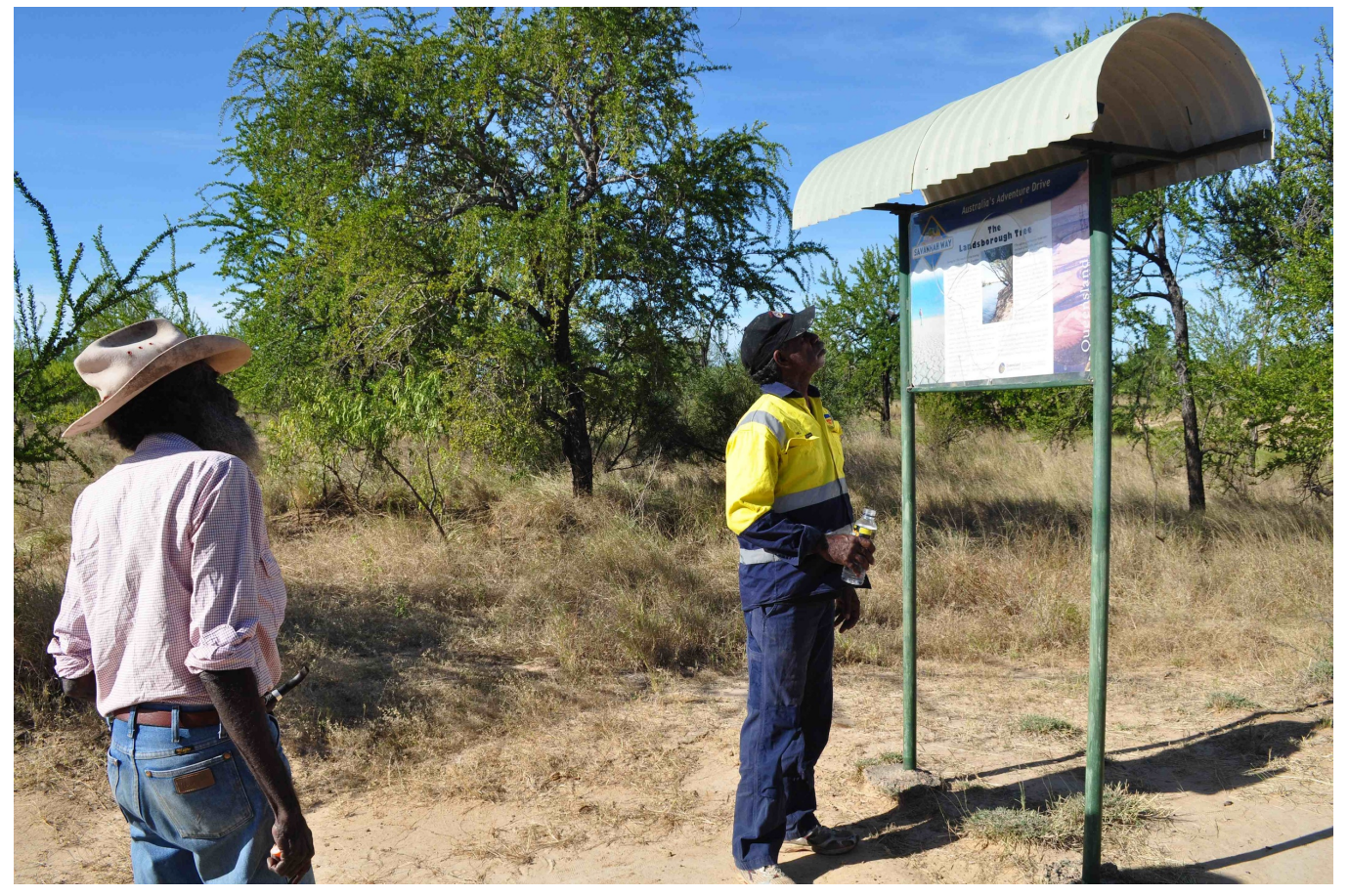

Photograph 3: Ganggalida people inspecting the Landsborough tree display

Source: photograph by author, July 2012

de-create sites associated with colonial history (as the author's solecism suggests). Alternatively, it is possible to see the note as a cryptic claim of responsibility by the arsonist, or an attemp by one of his or her supporters to credit this act to a supposed political campaign. Regardless of the interpretation, the attempt to explain the event introduces uncertainties, suggesting new avenues of enquiry extending outside the region. Moreover, even in Burketown, where the Landsborough tree seemed to polarise opinion along Aboriginal and non-Aboriginal lines, alternative readings of the tree existed. Commenting on the arson, a senior Ganggalida woman stated:

Us older people are upset ... Our ancestors adopted those people into this area, into the Aboriginal tribe. My old Dad he wanted to include them ... Those explorers Burke and Wills or whoever it was, Landsborough, he brought that tree from England.

That tree was in fact a Coolibah, in many respects an icon of Australia's native environment, beneath which the jolly swagman sat in the folk song 'Waltzing Matilda'. But here in this elderly woman's narrative it is transformed into something 
else: a tree from England, but a welcome one, one that took root in the Burketown soil, where it was drawn into Aboriginal cultural landscapes as well as nonAboriginal ones. More straightforwardly racialised interpretations of this event and the symbolism of this tree exist in Burketown and the broader Gulf region, but research that resists such simplistic interpretations produces a far richer account, highlighting hidden complexities as well as ambiguities.

- THE LIVING TREE

At Timber Creek in the Northern Territory, the Gregory tree beside the Victoria River provides a further example of the merits of research combining predominantly textual 'readings' of things with more open-ended ethnographic fieldwork, revealing a variety of meanings apart from or in addition to this tree's connection to conservative nationalist history. It is significant that the Gregory tree or Gregory trees (several trees are marked) are still alive, and are still so healthy they were brimming with fruit when I visited the site in June 2011. These trees are surrounded by texts that tell of the lives of the explorers-and indeed the explorer's own hand (or that of his amanuensis) is apparent in impressively neat copperplate script, marking the date June 2nd 1865-but they also suggest non-symbolic, nonrepresentational meanings. When I visited the site, those with whom I travelled got as close to the trees as they could, pressing their hands against the bark, 'as if to touch its possible deeper meanings', as the novelist Michael Ondaatje puts it in another context. ${ }^{32} \mathrm{~A}$ young non-Aboriginal woman at the site actually licked the bark of a tree, following the instructions on an information board that identified medicinal properties therein that were supposedly exploited by Aboriginal people in pre-colonial times. It is difficult to understand such actions as obeisance to the dictates of history; there is clearly something else happening here, evoking comparisons with the adoration of the cross in Christian ceremonies, a kind of tree worship suggestive of animism or 'new animism'.33 These trees are significant for their connection to the explorers, but they are clearly significant for other reasons too.

Unlike the trees at Borroloola and Burketown, these Gregory trees are also significant to Aboriginal people for their connection to a Dreaming. They were recently registered under the Northern Territory Sacred Sites Act, thereby receiving 


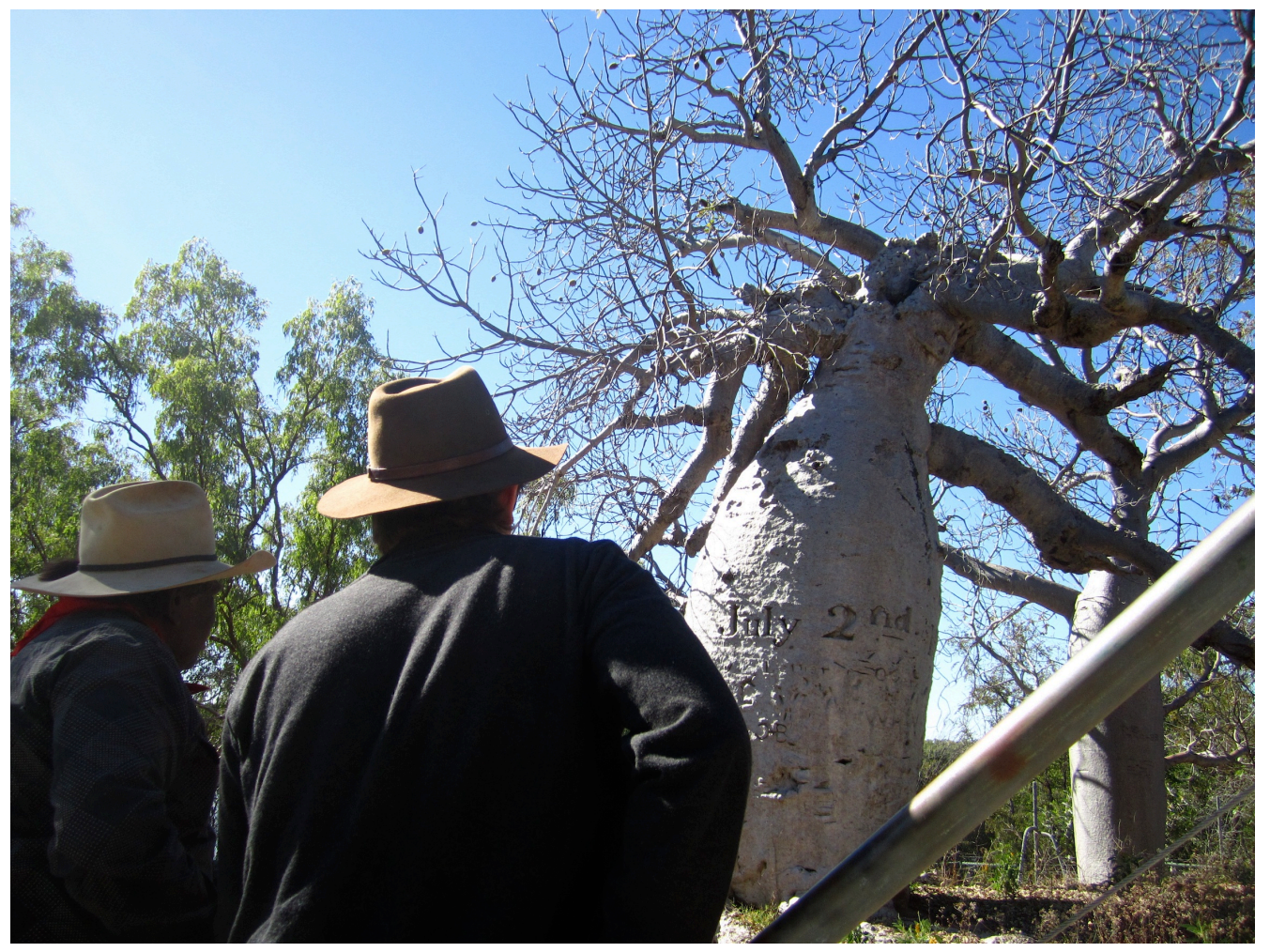

Image 4: Gregory tree

Source: photograph by author, July 2011

the highest protection possible under Northern Territory law. 'This place', I was told, 'is for [a Dreaming figure] ... left a couple of bottle [boab] trees'. The complexity of the associations between landscape, ancestors and totemic beings suggested here has been described by anthropologists elsewhere in terms of 'processes of metamorphosis, imprinting and externalisation', whereby things created by ancestral beings are 'thought to contain something of [the ancestor] himself within it ... imply[ing] a consubstantial relationship between the ancestor and his objectifications'. ${ }^{34}$ However, when I was talking about the significance of these trees with a senior Ngarinman person, he repeatedly emphasised their connection to the explorers:

When Gregory first come into the country there they [Aboriginal people] make friends with him ... They [Aboriginal people] nearly spear him when he first come in [but] they [Gregory's party] make friends with them [Aboriginal people], give them jam and tea. People from everywhere used to have ceremony ... That bin stopped when Gregory come in. They didn't 
have right [to stop people practicing ceremonies]. People bin get quieten them down, get hats and everything. That story from my Granddad and Dad's Granddad.

While this quotation vividly expresses a sense of injustice associated with the past, the story seemed to be offered in a spirit of reconciliation, reflecting a change in Aboriginal relations to the past. Indeed a week or so later, this man commented:

We [Aboriginal people] don't like to call you Whitefella. It [Whitefella] is like Blackfella. But like you don't call us Blackfella anymore ... I don't hear Whitefella call us Blackfella. That [being called Whitefella] must be hurting you. Like we happy with [being called] Aboriginal. But we gotta find another word [for you].

Like the senior Ganggalida woman whose response to the arson in Burketown I quoted earlier, these comments reflect a repositioning of Aboriginal identity in regard to narratives of the past. Such comments provide an insight into the kinds of revelation made possible by combining textual and ethnographic analyses, going beyond simplistically politicised interpretations of these trees into the realm in which non-symbolic, non-representational meanings are generated and regenerated without end.

\section{-CONCLUSION}

The divergent symbolic uses of the explorer trees of northern Australia might be cited as evidence of a broad contrast between Aboriginal and non-Aboriginal ways of thinking about the colonial past and the post-colonising present. But this contrast needs to be problematised. The social life of the three explorer trees I've discussed here highlights overlaps between Aboriginal and non-Aboriginal ways of thinking about trees, even in the overtly political context suggested by the association of the trees with European explorers. Reading the meaning of these trees without diligent ethnography carries the risk of merely producing a politicised interpretation, captive to contemporary forms of radicalism.

In Burketown, where I spent the most time trying to get to the bottom of what the Landsborough tree meant, some of the oldest Ganggalida people with connections to the area remember the stories of their elders, about the arrival of non-Aboriginal people when their own parents were young. A Ganggalida woman 
named Alice Gilbert was born near the site of the Landsborough tree towards the end of the nineteenth century. In the late 1960s, ethnographer John Dymock recorded her account of what she called Wild Time. ${ }^{35}$ She described how nonAboriginal people came to Burketown first without firearms; they were fought off, and then had to go away and invent better weapons in order to kill Aboriginal people when they came back. Stories about such Wild Time, retold by Alice Gilbert's elderly daughter Eva Gilbert, have been critical in securing Native Title rights and interests for Ganggalida people. In this context, the colonial past is ineluctably present, part of the historicity of the contemporary world. Heritage sites particularly dramatise such historicity, becoming central loci for struggles over identity.

In Burketown, where persons unknown burnt down the Landsborough tree, the struggle is ongoing, present in everyday life in all sorts of ways, as 'different stories vie for a place in history'. ${ }^{36}$ In early 2012, the Burketown pub-reputedly the town's oldest surviving building-also burnt down, generating another swirl of rumours. The cause of that fire remains unclear. Nevertheless, while the struggle over identity continues, to construe it simply as a conflict between a dominant national memory and another counter-memory (Aboriginal or otherwise) risks deploying a hopelessly essentialised notion of authenticity insofar as contemporary Australian identities are partly formed in relation to things like explorer trees. As Stuart Hall puts it, identities are 'the names we give to the different ways we are positioned by, and position ourselves in, the narratives of the past'. ${ }^{37}$ While scholars might seek to deconstruct such authenticity as identitarian mythology, we ought to take identity seriously. This means 'reading' the Leichhardt, Landsborough and Gregory trees not just for evidence of a pre-existing conflict between Aboriginal and non-Aboriginal people in Australia but also for the suggestion of other divergent responses, including new ones, where the meaning of exploration and colonisation is created, and re-created, along with the experience of place.

Richard J. Martin is a research fellow and consulting anthropologist in the School of Social Science at the University of Queensland. His academic research focuses on issues of land and identity in the southern Gulf of Carpentaria. He has also 
conducted applied research on Native Title claims and Aboriginal cultural heritage matters around Queensland.

\section{-ACKNOWLEDGEMENTS}

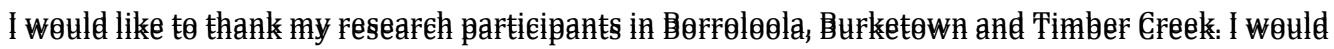
alsø like te thank Brefessør Bavid \$: Trigger, Brefesser Gareth Griffiths and Assøeiate Brøfessør Bebra McDougall for providing valuable feedback on earlier drafts. Fieldwork in the Gulf was supported by The University of Western Australia's Hackett scholarship, the Ernest and Evelyn Shacklock scholarship and the Graduate Research and Training Scheme award and subsequently by the Australian Research Council Discovery Project Number 1201 00662. The Carpentaria Land Council Aboriginal Corporation also provided support and assistance while I was conducting research in the Gulf. Fieldwork in the Victoria River District was facilitated by Daryl Wesley and Dr. Andrew McWilliam through the Australian Government's Attorney-General's Department-ANU Enterprises Native Title Field School and Intensive. Finally, I would also like to thank the Cultural Studies Review's anonymous reviewers for constructive comments.

\section{-NOTES}

1 Judy Cotton, Borroloola: Isolated and Interesting 1885-2005, Government Printer, Darwin, 2005.

${ }^{2}$ Leichhardt disappeared somewhere in the centre of the continent on his third expedition in 1848. As a result, much interest has historically been shown in trees marked with the letter ' $\mathrm{L}$ ' as a guide to the explorer's probable route on that expedition. Some debate continues as to which trees were actually marked by Leichhardt during these expeditions and which were marked by other explorers including George de la Tour and William Landsborough (who both also used an 'L'). I refer to this 'L' tree as a 'Leichhardt' tree throughout this article because that is how it is presented in the Borroloola Museum. ${ }^{3}$ Darrell Lewis suggests that this removal was occasioned by the threat of termites at the Calvert River site. D. Lewis, personal communication with the author, 21 March 2013.

4 Paul Carter, The Road to Botany Bay: An Exploration of Landscape and History, University of Minnesota Press, Minneapolis, 2010 [1987], p. xxii.

5 The tone of this debate is well captured in exchanges between David Trigger and Bob Hodge and Vijay Mishra, on the one hand, and Sandy Toussaint and Stephen Muecke on the other. It is noteworthy that outside the overtly politicised context of the 1990s, such debate appears to have died down, suggesting that interdisciplinary work is increasingly possible. See David Trigger, 'Review Article: Australian Cultural Studies: Radical Critique or Vacuous Posturing', Anthropological Forum: A Journal of Social Anthropology and Comparative Sociology, vol. 6, no. 3, 1993, p. 607; Bob Hodge and Vijay Mishra, 'Anthropology and/or/as 'Cultural Studies'? A Response to Trigger', Anthropological Forum: A Journal 
of Social Anthropology and Comparative Sociology, vol. 6, no. 4, 1993, p. 614; Sandy Toussaint, 'Review: Textual Spaces: Aboriginality and Cultural Studies by Stephen Muecke', Oceania, vol. 66, no. 2, 1995, pp. 171-3; Stephen Muecke, 'Cultural Studies and Anthropology', Oceania, vol. 66, no. 3, 1996, p. 252.

6 Marilyn Strathern, 'Artefacts of History: Events and the Interpretation of Images', in Culture and History in the Pacific, ed. Jukka Siikala, Finnish Anthropological Society, Helsinki, 1990.

${ }^{7}$ Amiria Henare, Martin Holbraad and Sari Wastell, Thinking Through Things: Theorising Artefacts Ethnographically, Routledge, London, 2007, p. 3.

8 The work of Nigel Thrift and others offers insights into such non-symbolic interpretation, albeit in a way that remains avowedly 'experimental'. For Thrift, material objects are part of hybrid assemblages imbued with relational agency; his non-representational theory critiques the 'methodological fetishism' of the conventional disciplines, calling for a 'poetics of the release of energy that might be thought to resemble play'. Nigel Thrift, Non-Representational Theory: Space, Politics, Affect, Routledge, London, 2008, p. 12.

${ }^{9}$ Ernestine Hill, The Great Australian Loneliness, Robertson and Mullens, Melbourne, 1940; Ernestine Hill, The Territory, Angus and Robertson, Sydney, 1951; Glenville Pike, Queensland Frontier, Rigby Limited, Adelaide, 1978; Sarah Murgatroyd, The Dig Tree: The Story of Burke and Wills, Text Publishing, Melbourne, 2002.

${ }^{10}$ Erich Kolig, 'Captain Cook in the Western Kimberleys', in Aborigines of the West: Their Past and their Present, eds Ronald M. Berndt and Catherine H. Berndt University of Western Australia Press, Perth, 1979; Athol Chase, 'Aboriginal Perspectives: A Comment', in Ecology and Management of the World's Savannas, eds John C. Tothill \& John J. Mott, Australian Academy of Science in conjunction with Commonwealth Agricultural Bureaux, Canberra, 1985, pp. 166-7; Kenneth Maddock, 'Myth, History and a Sense of Oneself', in Past and Present: The Construction of Aboriginality, ed. Jeremy Beckett, Aboriginal Studies Press for the Australian Institute of Aboriginal Studies, Canberra, ACT, 1988, pp. 1130; Deborah Bird Rose, 'The Saga of Captain Cook: Morality in Aboriginal and European Law', Australian Aboriginal Studies, vol. 2, 1984, pp. 24-39; Deborah Bird Rose, Hidden Histories: Black Stories from Victoria River Downs, Humbert River and Wave Hill Stations, Aboriginal Studies Press, Canberra, 1991; Chris Healy, From the Ruins of Colonialism: History as Social Memory, Cambridge University Press, Melbourne, 1997; Stephen Muecke, 'A Touching and Contagious Captain Cook: Thinking History Through Things', Cultural Studies Review, vol. 14, no. 1, 2008.

11 Healy, p. 11.

12 Muecke, 'A Touching and Contagious Captain Cook', p. 34.

13 Ibid., p. 41.

${ }^{14}$ Manning Clark, A History of Australia, vol. I, Melbourne University Press, Melbourne, 1962, p. 50.

15 Patrick White, Voss, Random House, London, 1994 [1957], p. 443.

16 William E.H. Stanner, The Dreaming and Other Essays, Black Inc. Agenda, Melbourne, 2009, p. 189. 
17 Mark McKenna, Looking for Blackfellas' Point: An Australian History of Place, University of New South Wales Press, Sydney, 2002, p. 87.

18 Ibid., pp. 84-5.

${ }^{19}$ Stuart Macintyre and Anna Clark, The History Wars, Melbourne University Press, Melbourne, 2003.

20 Cited in Paul Kelly, March of the Patriots: The Struggle for Modern Australia, Melbourne University Press, Melbourne, 2009, p. 71.

${ }^{21}$ Clark, pp. 495-6.

22 Svetlana Boym, The Future of Nostalgia, Basic Books, New York, 2001.

23 Scott A. Sandage, 'A Marble House Divided: The Lincoln Memorial, the Civil Rights Movement, and the Politics of Memory, 1939-1963', The Journal of American History, vol. 80, no. 1, 1993, pp. 136.

24 Clifford Geertz, 'Deep Play: Notes on the Balinese Cockfights', in Myth, Symbol, and Culture, ed. Clifford Geertz, Norton, New York, 1974, p. 29.

25 For an account of text as 'a metadiscursive construct' referring to 'actual cultural practices' see Michael Silverstein and Greg Urban (eds), Natural Histories of Discourse, University of Chicago Press, Chicago, 1996, p. 2.

26 The anthropologist Bruno Latour is a key exponent of these theories. See Bruno Latour, Reassembling the Social: An Introduction to Actor-Network Theory, Oxford University Press, Oxford. See also Stephen Muecke, 'Motorcycles, Snails, Latour: Criticism without Judgement', Cultural Studies Review, vol. 18, no. $1,2012$.

27 Daimantina Touring Company, <http://www.diamantinatour.com.au/expeditions/burke_wills/burke_wills.html>.

28 James S. Laurie (ed.), Landsborough's Exploration of Australia from Carpentaria to Melbourne, with Especial Reference to the Settlement of Available Country, Thomas Murby, London, 1866, n.p.

${ }^{29}$ Gwen Trundle, 'Landsborough, William (1825-1886)' in Australian Dictionary of Biography, vol. 5, Melbourne University Press, Melbourne, 1974.

30 Ivy Jensen, 'Vandals Burn Down Historic Tree', North West Star, 23 December 2002, p. 1.

31 Geertz, 'Deep Play', pp. 1-37.

32 Michael Ondaatje, The English Patient, Alfred A. Knopft, New York, 1992, p. 243.

33 Nicolas Peterson uses the term 'new animists' to describe those influenced by the deep ecology movement and other anti-modernist views. See Nicolas Peterson, 'Is the Aboriginal Landscape Sentient? Animism, the New Animism and the Warlpiri', Oceania, vol. 81, no. 2, 2011, pp. 167-79. 34 Peterson, p. 171; Nancy Munn, 'The Transformation of Subjects into Objects in Walbiri and Pitjantjatjara Myth', in Australian Aboriginal Anthropology, ed. Ronald Berndt, Perth, University of Western Australia, 1970, p. 142.

35 John Dymock, 'Of Bows and Arrows and Monkey Men: The Nature of Culture Contact in the Southern Gulf Country', Australian Institute for Maritime Archaeology Conference, Darwin, NT, 1998, pp. 1-20. 
36 Marita Sturkin, Tangled Memories: The Vietnam War, the Aids Epidemic, and the Politics of Remembering, University of California Press, Berkeley, 1997, p. 1.

37 Stuart Hall, 'Cultural Identity and Diaspora', in Identity: Community, Culture, Difference, ed. J Rutherford, Lawrence \& Wishart, London, 1990, pp. 223-37. 